International Journal of Business and Management 4 (3): 40-49, 2020

e-ISSN: 2590-3721

(C) RMP Publications, 2020

DOI: $10.26666 / \mathrm{rmp} . \mathrm{ijbm} .2020 .3 .5$

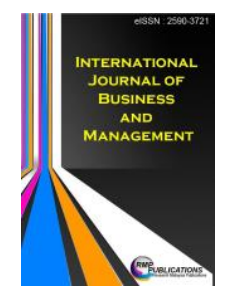

\title{
Current Research in Zakat Accounting Research
}

\author{
Roslee Bin Uyob \\ Department of Commerce, Politeknik Sultan Abdul Halim Muadzam Shah (POLIMAS), \\ Jitra Kedah, Malaysia.
}

\begin{abstract}
Zakat Accounting is part of accounting which concerned with determination and valuation of wealth and income according to the rules set by Islamic Shariah law. In Zakat Accounting it also involves recording, interpreting, presentation and disclosure of accounting information. This study presents an analysis regarding the current research in the area of Zakat Accounting using two database system which is Scopus and Google scholar. The objective of this study is to provide the current trend in Zakat Accounting using bibliometric analysis. 35 Articles has been extracted from Scopus and Google database and exported to Mendelay software to conduct bibliometric analysis. The results shows that the research in zakat accounting has been increasing and constantly publish in the number of articles since 2011 onwards. However, they are still lacks of research that has been conducted in the area of Zakat accounting. By conducting this study, we hope it will give a general picture of a research in Zakat Accounting, which is very useful in identifying the main trends, future gaps and direction of the research in the area of Zakat Accounting in the future.
\end{abstract}

Key words: Zakat Accounting, Zakat, Zakat literature, Bibliometric analysis

\section{INTRODUCTION}

In literacy, the term Zakat means blessing, growth, development, purity and neatness. Many Islamic scholars define Zakat as the part of property that requires the owner to give to the proper person when achieved a certain requirement to purify its belonging properties as a worship to Allah SWT [1]. In Islam, it's become an obligation to the Muslim people to pay Zakat if those properties belong to them was met the requirement and exceeded the limit (Nisab) and time required (Haul) [2].

The Ibadah ${ }^{1}$ of Zakat become the third pillar of Islam after prayer Ibadah. Most of the Islamic scholar stated that the word of Zakat has been stated 82 time in Al Quran but according to al Qardawi², the word of Zakat has been stated 30 times and 27 words has been stated together with order to perform solat in regular prayers Ibadah. This indicate that the Zakat Ibadah is one of the important aspects in Islamic religion [3].

\footnotetext{
${ }^{1}$ The term 'ibadah in arabic dictionary means submission and surrender. According to sheikh ibn sa'di, worship or 'ibadah is "a comprehensive term includes all what Allah loves of beliefs, inward and outward deeds. Doing good deeds or refraining from sins are considered a worship which draws a person closer to
}

Many Islamic scholar and economic experts has agreed that Zakat has been tested and become most effective tool to fight poverty and all unwanted consequences [4]. The purpose of Zakat is to reduce the concentration of wealth in few hands, to ensure equitable wealth redistribution among people, to fight poverty in the society, to achieve social security and economic prosperity [2].

To allocate and distribute the Zakat, Al Quran (9:60) has stated that only eight types of group are entitled to receive the Zakat. The eight types of them are, for poverty eradication such as the poor, the needy, the debtors, the slaves (who want to release themselves from captivity), the travelers in the way of Allah, the collector of Zakat (Zakat administrative), those who are new convert to Islam, and those who perform da'wah ${ }^{3}$ and taken action in the way of Allah [2]. Although these eight types of people have been mentioned in the Qur'an, but the priority to allocate the Zakat funds must be accorded to the alleviation of poverty through assistance to the poor and the needy [5].

Allah. Likewise, a person who abandons sins for Allah's sake also worships his lord and gets closer to him".

$2 \mathrm{Dr}$ Al Qardawi is one of the respected ulama in Islamic scholar. ${ }^{3}$ Da'wah usually means inviting to Islam. Arabic دعوة da'wah means literally "calling out" or "inviting", being used as an active participle of a verb meaning in various "calling, inviting".

Corresponding Author: Roslee Bin Uyob, Department of Commerce, Politeknik Sultan Abdul Halim Muadzam Shah (POLIMAS), Jitra Kedah, Malaysia, email: rosleeuyob@gmail.com 
Generally, the research in Zakat field of academic environment has been expanding from time to time. Zakat is no longer been perceived merely limited to the religious or sharia studies only but it has been widen to include in other issue such social economics studies [3].

The need to make a computation and assessment to identify the amount of Zakat obligation, the need to distribute and manage the Zakat fund by Zakat institution, the expanding of the type of financial instrument and new term of asset belonging gives the fact that Zakat was not related to the theory and only, but it mostly involves with financial form of Ibadah. To compute and make an assessment, accounting will play a fundamental role to determine a proper and fair assessment of payable amount Zakat [6]. The link between accounting and Zakat has stimulated and become wide-ranging discussion among all academicians and practitioners.

Therefore, the objective of this study is to examine current research in Zakat Accounting using bibliometric analysis. Through this analysis, it will provide a complete overview of the current trends in the Zakat Accounting research over time. The information regarding the Zakat Accounting research is collected from the two database system which is Scopus and Goggle Scholar. By using more than one database, it will provide more search result with more comprehensive article in order to get more accurate data regarding Zakat accounting research.

This study comprises of several phase. For the first phase, this study will explain about the background of the study, objective of the study and the potential contribution of the study. The second phase will provide the explanation of bibliometric analysis and related literature review regarding Zakat Accounting. The next phase of this study will outline the methodology of this study including scope of the study review analysis and the classification of information about each paper that become part of the analysis. The next phase will present the results of our analysis including number of publications by year and publisher, classification according to the research type, approach and analysis based on subject area of articles. Lastly, this study will conclude the paper with a summary of major findings and suggestions about the possible future research directions of Zakat Accounting research.

\section{LITERATURE REVIEWS}

\section{Overview of Bibliometric Analysis}

In the field of information science, bibliometric analysis has been widely known and become fundamental studies in that classifies bibliographic material quantitatively. In the literature, there are many discussions regarding the definition of bibliometric analysis. According to [7] bibliometric analysis is an analysis that provided a complete overview of the concept from the general perspective of informetric. The advantage of bibliometrics is that it provides a general picture of a research area, which is very useful in identifying the most influential research and identifying the main trends over time [8].

The use of bibliometric analysis has been developed in many disciplines area such as economics, entrepreneurship, production and operation management, marketing, finance and accounting research area. In bibliometric analysis, many researchers use different method in order to analyse the result. A research conducted by [9] use citation analysis and the number of publications to identify the most influential authors and institutions in 30 selected management journals from 1981 to 2004. A research conducted by [10] use list of most influential authors among Full-Time Academic Hand Surgeons Affiliated With Fellowship Programs according to the h-index. While [11] use bibliometric indicators in the context of regional repositories to propose $\mathrm{D}$ index. Based on the previous study, it shows that bibliometric analysis has become useful tool to see the trend in the specific field of study.

\section{Overview of Zakat Accounting}

Zakat Accounting is part of accounting which concerned with determination and valuation of wealth and income. In Zakat Accounting, the Zakat amount is being measures according to the rules set by shariah law. The process in Zakat Accounting is not only to measure and make valuation, but it also involves recording, interpreting, presentation and disclosure of accounting information. Basically, the accounting and valuation for Zakat are done in line with shariah compliance which is against interest based transactions and the prediction of future [6]. The choice and perceptions of accounting policy in Islam especially in Zakat perspective is different from the typical western business. In Islam, the perceptions of Zakat is aiming to purifying and contribute to the socio justice rather than typical western business which see the tax payable as an expenses and will try to minimizing the tax in order to maximizing the profit [6]. The Muslim belief that the wealth and properties are not belongs to them in this world, but the properties and wealth are only a trust (amanah) that given by Allah SWT to them. Its different concept with typical western business that stated the wealth properties of the business are $100 \%$ belong to the shareholders [3]. Due to this 
misconception regarding the Zakat it is feared that some negative attitudes and behaviours in performing this obligation might arise among some corporations. Thus, the standard and the accounting treatment especially in Zakat perspective play an important role to make sure Muslim company comply with this Zakat obligation [3].

In the perspective of accounting, Zakat is calculated based on wealth not income or profit. The calculation of Zakat is made based on the majorly adjusted the statement of financial position to determine the Zakat obligation for business. The adjustment has been made by comparing Zakat able asset and allowable Zakat liabilities to determine net Zakat able asset. [12][13].

The conventional accounting and Zakat Accounting are basically different in principal [14][15]. The different of principal such as going concern concept, the entity concept, the measurement and valuation, the periodicity and others principal make it impossible to use conventional final account to determine Zakat [16] To determine zakat, they will prepare a new set of accounts which exclusively for the purpose of calculating the Zakat obligation rather than adjusting the prepared conventional accounting final accounts [17].

Many Islamic scholar stated that the calculation of asset and deductible expenses to determine the amount of Zakat liabilities especially for business is depending on the provisions in Zakat law which based on Islamic scholar and expert captured on the Islamic injunction [3][18][19][20]. The formulation to determine and computing the amount of Zakat has not been detailed in the main source in Islamic sharia. Its only stated the basic concept and to determine the obligation is depending on the current situation. To determine the Zakat obligation, the amount is calculating based on the amount of current belonging wealth which comply with adequate conditions. Therefore, it is depending on current situation of wealth determination. In current situation, the need to developed Zakat Accounting method is needed to determine the Zakat obligations for use by Zakat institution, agencies, nongovernmental organization and individuals. The accounting guideline for Zakat may differ from opinion of the Islamic expert with respected to the law and fatwa differ within the context, time and environment are in questions [13]. The development of the Zakat Accounting standard, pronouncement, manuals and templates will greatly assist many majority Muslim countries to attracted and encouraged the voluntary Zakat compliance by the Muslim people [21].

\section{METHODOLOGY}

To conduct this study, all related articles in Zakat accounting has been search using the Scopus and Goggle scholar database. The key word "Zakat Accounting" has been type in the search tab with restricted only to the keyword which available in the title and abstract of the articles. Based on the search findings, 13 articles in Scopus and 31 articles in Google scholar has been found in the database. All article in both database has been download and exported to the Mendelay software for further actions. By using Mendelay, all article has been checked first to see their accuracy of the article information and filter for duplicate article. After filter for duplicate article and numerous info modification and recheck, 35 articles have been selected for bibliometric analysis including 33 publish article and 2 thesis paper. Based on selected articles, the following information associated with the article was extracted from the file: Author, Title, Journal Name, Year, Abstract, Volume, Issue and Page. The relevant information was copied into Excel to facilitate detailed analysis. The detail step and detail article selected can be show below:

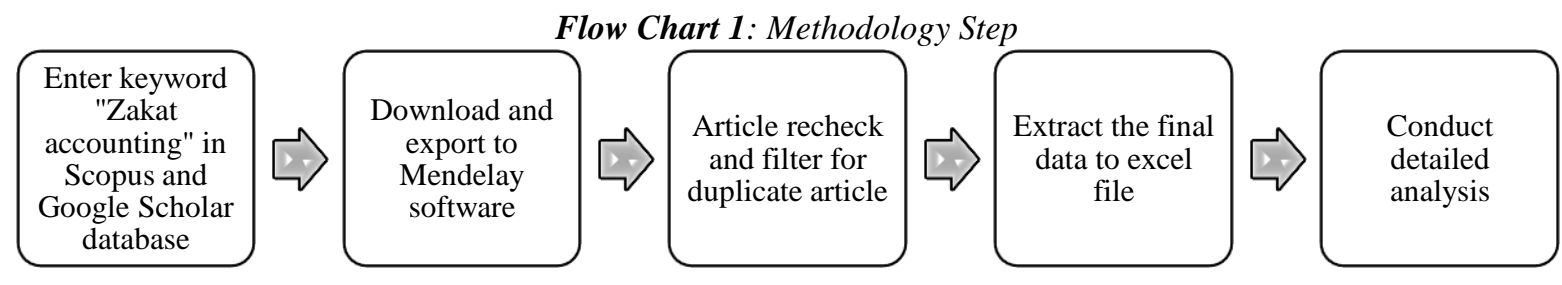


Table 1: Selected Article related to Zakat Accounting found in Scopus and Google Scholar database

\begin{tabular}{|c|c|c|}
\hline No. & Title & Author \\
\hline 1 & $\begin{array}{l}\text { Implementation of Zakat Accounting In Amil Zakat Institute (LAZ) In Jember } \\
\text { (Reviewed From Zakah Shariah : PSAK } 101 \text { And PSAK 109) }\end{array}$ & {$[22]$} \\
\hline 2 & $\begin{array}{l}\text { Implementation Psak } 109 \text { About Accounting Of Zakat } \\
\text { At Baznas Of West Nusa Tenggara Province Indonesia }\end{array}$ & [23] \\
\hline 3 & Accounting For Zakat: The Accountability Of Indonesian Zakat Agencies & [24] \\
\hline 4 & Current Methods of Business Zakat Accounting in Malaysia & {$[25]$} \\
\hline 5 & $\begin{array}{l}\text { Effects of Accounting Information Quality, Accountability, and Transparency } \\
\text { on Zakat Acceptance }\end{array}$ & [26] \\
\hline 6 & $\begin{array}{l}\text { Accounting Of Zakat, Infak And Alms In Transparency And Accountability } \\
\text { In Laz Dompet Amanah Umat Sidoarjo }\end{array}$ & {$[27]$} \\
\hline 7 & $\begin{array}{l}\text { The Relationship between Paddy Zakat Accounting and the Social Wellbeing } \\
\text { Aspect of Farmers in Perlis, Malaysia }\end{array}$ & {$[28]$} \\
\hline 8 & $\begin{array}{l}\text { Cause and effect of accounting information system: A study in national Zakat } \\
\text { management organization }\end{array}$ & [29] \\
\hline 9 & $\begin{array}{l}\text { The influence of Transformational Leadership on the Success of Accounting } \\
\text { Information Systems Implementation (Survey on National Zakat Management } \\
\text { Institution of West Java) }\end{array}$ & {$[30]$} \\
\hline 10 & IFRS and Saudi accounting standards: A critical investigation & [31] \\
\hline 11 & $\begin{array}{l}\text { The influence of transformational leadership on the success of accounting } \\
\text { information systems implementation (Survey on national Zakat management } \\
\text { institution of West Java) }\end{array}$ & {$[32]$} \\
\hline 12 & $\begin{array}{l}\text { Statement of Financial Accounting Standard (PSAK) No. } 109 \text { and Its } \\
\text { Implementation in Several Zakat Management Organizations in Malang, East } \\
\text { Java }\end{array}$ & [33] \\
\hline 13 & $\begin{array}{l}\text { Accounting For Zakat on Income Critical Study Based on Government } \\
\text { Regulation (Case Study in Aceh Province of Indonesia) }\end{array}$ & {$[34]$} \\
\hline 14 & $\begin{array}{l}\text { Zakat Accounting: Metaphor and accounting treatment for business } \\
\text { organization }\end{array}$ & {$[35]$} \\
\hline 15 & The Principle of Zakat, Infaq, and Shadaqah Accounting Based Sfas 109 & [36] \\
\hline 16 & Zakat and accounting valuation model & [6] \\
\hline 17 & Revisiting estimation methods of business Zakat and related tax incentives & [13] \\
\hline 18 & $\begin{array}{l}\text { Utilization and Accounting of Zakat for Productive Purposes in Indonesia: A } \\
\text { Review }\end{array}$ & {$[37]$} \\
\hline 19 & $\begin{array}{l}\text { Implementation Of Accounting Zakat at The Organization Of Zakat Based On } \\
\text { SFAS } 109 \text { About Accounting Zakat And Infak / Sedekah (CASE Studies In } \\
\text { Organization Of zakat District Banyuwangi) }\end{array}$ & [38] \\
\hline 20 & $\begin{array}{l}\text { Management Accounting Practices In Non-Profit Religious Organization: A } \\
\text { Case Study In Lembaga Zakat Selangor (LZS) }\end{array}$ & [39] \\
\hline 21 & Agricultural Zakat Accounting in Malaysia & [40] \\
\hline 22 & $\begin{array}{l}\text { A study on the zakat and infaq or sodaqoh accounting application under SFAS } \\
109 \text { in Al-Falah Social Fund Foundation (YDSF) Surabaya }\end{array}$ & [41] \\
\hline 23 & The dynamics of capital structure in the presence of Zakat and corporate tax & [42] \\
\hline 24 & Sustainable Zakat Accounting in Malaysia: An analysis & [43] \\
\hline 25 & Zakat expert system & [44] \\
\hline 26 & $\begin{array}{l}\text { Proposed best practices of financial information disclosure for Zakat } \\
\text { institutions: A case study of Malaysia }\end{array}$ & {$[12]$} \\
\hline 27 & $\begin{array}{l}\text { Shari'ah disclosures in Malaysian and Indonesian Islamic banks:The Shari'ah } \\
\text { governance system }\end{array}$ & {$[45]$} \\
\hline 28 & $\begin{array}{l}\text { The Influence Of The Accounting Managers' Knowledge And The Top } \\
\text { Managements' Support On The Accounting Information System And Its } \\
\text { Impact On The Quality Of Accounting Information: A Case Of Zakat } \\
\text { Institutions In Bandung }\end{array}$ & [46] \\
\hline 29 & $\begin{array}{l}\text { Changes in management accounting, innovation and person job fit practices in } \\
\text { Lembaga Zakat Selangor }\end{array}$ & [47] \\
\hline
\end{tabular}


Roslee/ International Journal of Business and Management, 4(3) 2020, Pages: 40-49

\begin{tabular}{|c|l|l|}
\hline 30 & $\begin{array}{l}\text { Zakat and tax reporting: Disclosures practices of Shariah compliance } \\
\text { companies }\end{array}$ & {$[48]$} \\
\hline 31 & Business Zakat Accounting and Taxation in Malaysia & {$[49]$} \\
\hline 32 & Accounting treatment for corporate Zakat: a critical review & {$[3]$} \\
\hline 33 & A Zakat Accounting Standard (ZAS) for Malaysian Companies & {$[50]$} \\
\hline 34 & Accounting systems and recording procedures in the early Islamic state & {$[51]$} \\
\hline 35 & $\begin{array}{l}\text { Were islamic records precursors to accounting books based on the Italian } \\
\text { method? }\end{array}$ & {$[52]$} \\
\hline
\end{tabular}

\section{DATA ANALYSIS}

\section{Number of Publications by Year}

Table 2 presents the distribution of articles by year. There were 33 articles in total published related to Zakat Accounting from the year 2000 until 2018. The most article published are on 2017 (9 article, $27 \%$ ), and there is no article being published in the year 2001,2002,2003,2005,2006,2008, and 2010 . However the trend shows that they are increasing and constantly publish in the number of article since 2011 onwards.

Table 2: Number of publications by year

\begin{tabular}{|l|l|l|}
\hline Year & Number of articles & Percentage \\
\hline 2018 & 2 & $6 \%$ \\
\hline 2017 & 9 & $27 \%$ \\
\hline 2016 & 6 & $19 \%$ \\
\hline 2015 & 1 & $3 \%$ \\
\hline 2014 & 7 & $21 \%$ \\
\hline 2013 & 1 & $3 \%$ \\
\hline 2012 & 1 & $3 \%$ \\
\hline 2011 & 1 & $3 \%$ \\
\hline 2010 & 0 & - \\
\hline 2009 & 2 & $6 \%$ \\
\hline 2008 & 0 & - \\
\hline 2007 & 1 & $3 \%$ \\
\hline 2006 & 0 & - \\
\hline 2005 & 0 & - \\
\hline 2004 & 1 & $3 \%$ \\
\hline 2003 & 0 & - \\
\hline 2002 & 0 & - \\
\hline 2001 & 0 & - \\
\hline 2000 & 1 & $3 \%$ \\
\hline Total & 33 & $100 \%$ \\
\hline
\end{tabular}

Numbers of article published by publisher.

Table 3 presents the distribution of articles publish by the publisher. Currently, 27 publishers publish the article in Zakat Accounting area of study in Scopus and Goggle Scholar database. However, for the purpose of this study, the author has divided into 4 categories of publisher which is international journal publisher, journal publisher, proceeding and conference publisher, and others. From the analysis, the most publishers publish article related to Zakat Accounting is Journal publisher 15 articles (46\%), International Journal publisher 8 articles (24\%), proceeding and conference publisher 6 articles (18\%) and others 4 articles (12\%).

Table 3: Numbers of article published by publisher.

\begin{tabular}{|c|c|c|c|}
\hline Publisher & $\begin{array}{l}\text { Number } \\
\text { of } \\
\text { articles }\end{array}$ & Percentage & Total \\
\hline $\begin{array}{l}\text { International } \\
\text { Journal of } \\
\text { Academic } \\
\text { Research in } \\
\text { Business and } \\
\text { Social Sciences } \\
\end{array}$ & 2 & $6 \%$ & \multirow{6}{*}{$\begin{array}{l}8- \\
(24 \%)\end{array}$} \\
\hline $\begin{array}{l}\text { International } \\
\text { Journal of Islamic } \\
\text { and Middle } \\
\text { Eastern Finance } \\
\text { and Management }\end{array}$ & 2 & $6 \%$ & \\
\hline $\begin{array}{l}\text { International } \\
\text { Journal of New } \\
\text { Technology and } \\
\text { Research (IJNTR) }\end{array}$ & 1 & $3 \%$ & \\
\hline $\begin{array}{l}\text { International } \\
\text { Journal of } \\
\text { Economics, } \\
\text { Commerce and } \\
\text { Management } \\
\end{array}$ & 1 & $3 \%$ & \\
\hline $\begin{array}{l}\text { International } \\
\text { Journal of } \\
\text { Disclosure and } \\
\text { Governance }\end{array}$ & 1 & $3 \%$ & \\
\hline $\begin{array}{l}\text { International } \\
\text { Journal of } \\
\text { Business, } \\
\text { Accounting and } \\
\text { Management }\end{array}$ & 1 & $3 \%$ & \\
\hline $\begin{array}{l}\text { Journal of } \\
\text { Engineering and } \\
\text { Applied Sciences }\end{array}$ & 2 & $6 \%$ & \multirow{5}{*}{$\begin{array}{l}15- \\
(46 \%)\end{array}$} \\
\hline $\begin{array}{l}\text { Journal of Islamic } \\
\text { Accounting and } \\
\text { Business Research }\end{array}$ & 2 & $6 \%$ & \\
\hline $\begin{array}{l}\text { Accounting } \\
\text { Historians Journal }\end{array}$ & 2 & $6 \%$ & \\
\hline $\begin{array}{l}\text { Journal of Reviews } \\
\text { on Global } \\
\text { Economics } \\
\end{array}$ & 1 & $3 \%$ & \\
\hline $\begin{array}{l}\text { Journal of } \\
\text { Accounting and } \\
\text { Business } \\
\text { Education }\end{array}$ & 1 & $3 \%$ & \\
\hline
\end{tabular}




\begin{tabular}{|c|c|c|c|}
\hline $\begin{array}{l}\text { Journal of } \\
\text { Administrative and } \\
\text { Business Studies } \\
\end{array}$ & 1 & $3 \%$ & \\
\hline $\begin{array}{l}\text { Journal Of Global } \\
\text { Management }\end{array}$ & 1 & $3 \%$ & \\
\hline $\begin{array}{l}\text { World Applied } \\
\text { Sciences Journal } \\
\end{array}$ & 1 & $3 \%$ & \\
\hline $\begin{array}{l}\text { The American } \\
\text { Journal of Islamic } \\
\text { Social Sciences }\end{array}$ & 1 & $3 \%$ & \\
\hline $\begin{array}{l}\text { Mediterranean } \\
\text { Journal of Social } \\
\text { Sciences }\end{array}$ & 1 & $3 \%$ & \\
\hline $\begin{array}{l}\text { Shirkah: Journal of } \\
\text { Economics and } \\
\text { Business }\end{array}$ & 1 & $3 \%$ & \\
\hline $\begin{array}{l}\text { Journal.Um- } \\
\text { Surabaya.Ac.Id }\end{array}$ & 1 & $6 \%$ & \\
\hline $\begin{array}{l}\text { Proceeding of the } \\
\text { 4th International } \\
\text { Conference on } \\
\text { Management and } \\
\text { Muamalah }\end{array}$ & 2 & $6 \%$ & \multirow{5}{*}{$\begin{array}{l}6 \\
18 \%\end{array}$} \\
\hline $\begin{array}{l}\text { Proceedings of the } \\
\text { European } \\
\text { Conference on } \\
\text { Knowledge } \\
\text { Management, } \\
\text { ECKM }\end{array}$ & 1 & $3 \%$ & \\
\hline $\begin{array}{l}\text { Procedia - Social } \\
\text { and Behavioral } \\
\text { Sciences }\end{array}$ & 1 & $3 \%$ & \\
\hline $\begin{array}{l}\text { Conference on } \\
\text { Islamic } \\
\text { Perspectives on } \\
\text { Management and } \\
\text { Finance } \\
\end{array}$ & 1 & $3 \%$ & \\
\hline $\begin{array}{l}2011 \text { IEEE } \\
\text { Colloquium on } \\
\text { Humanities, } \\
\text { Science and } \\
\text { Engineering, } \\
\text { CHUSER 2011 }\end{array}$ & 1 & $3 \%$ & \\
\hline MIMBAR & 1 & $3 \%$ & \multirow{4}{*}{$\begin{array}{l}4- \\
12 \%\end{array}$} \\
\hline $\begin{array}{l}\text { Munich Personal } \\
\text { RePEc Archive }\end{array}$ & 1 & $3 \%$ & \\
\hline $\begin{array}{l}\text { The Indonesian } \\
\text { Accounting } \\
\text { Review }\end{array}$ & 1 & $3 \%$ & \\
\hline $\begin{array}{l}\text { Artikel Ilmiah } \\
\text { Mahasiswa }\end{array}$ & 1 & $3 \%$ & \\
\hline
\end{tabular}

\section{Type of document publish}

Table 4 present the number of documents according to type. The most document in Zakat Accounting publish in the Scopus and Goggle Scholar database is article (22 documents, 63\%), the second type of document is conference paper ( 6 documents, $15 \%$ ), the third type of document is review paper (5 documents, 14\%) and lastly thesis paper (2 document, $6 \%$ ).
Table 4: Type of document publish

\begin{tabular}{|l|l|l|}
\hline $\begin{array}{l}\text { Type of } \\
\text { document }\end{array}$ & $\begin{array}{l}\text { Number of } \\
\text { documents }\end{array}$ & Percentage \\
\hline Article & 22 & $63 \%$ \\
\hline Review paper & 5 & $14 \%$ \\
\hline $\begin{array}{l}\text { Conference } \\
\text { paper }\end{array}$ & 6 & $17 \%$ \\
\hline Thesis & 2 & $6 \%$ \\
\hline
\end{tabular}

\section{Research Types of Each Publication}

Table 5 shows the types of research used for every article. Basically, there are four types of research design which is analytical, descriptive, empirical and exploratory research [53]. In analytical research, the research attempts to establish why and how it came to be. It is usually concerning with causeeffect relationships. Meanwhile, in descriptive research it attempts to identify, describe, or examine what is it. In descriptive research it will use description, classification, measurement, and comparison to describe certain phenomena. An empirical research method is a type of research methods in which the empirical observations or data are collected in order to answer certain particular research questions. Lastly, in exploratory research method they are few or no previous studies exist, and predictive research is to speculate on future possibilities after further study of available proof of cause and effect. Most publications contained all of four above-mentioned research types. Findings show that most articles (14 articles) are descriptive type in nature, followed by empirical ( 8 article), exploratory (8 articles) and lastly analytical (5 articles).

Table 5: Research Types of Each Publication

\begin{tabular}{|c|c|c|c|c|}
\hline Year & \multicolumn{4}{|c|}{ Research Type } \\
\hline & Analytical & Descriptive & Empirical & Exploratory \\
\hline 2018 & 1 & 1 & & \\
\hline 2017 & 3 & 2 & 3 & 1 \\
\hline 2016 & & 4 & 1 & 1 \\
\hline 2015 & & & 1 & 1 \\
\hline 2014 & 1 & 1 & 1 & 4 \\
\hline 2013 & & & 1 & \\
\hline 2012 & & 1 & & \\
\hline 2011 & & 1 & 1 & \\
\hline 2009 & & 2 & & \\
\hline 2007 & & & & 1 \\
\hline 2004 & & 1 & & \\
\hline 2000 & & 1 & & \\
\hline Total & 5 & 14 & 8 & 8 \\
\hline
\end{tabular}

\section{Research Approaches of Each Publication}

[54] stated that, there are three different approaches in research which is qualitative (subjective approach), quantitative (numerical analysis) and mixed method (combine both approaches). Table 6 shows the methods of research used for every article published in this study. Most of the articles are quantitative methods (17 articles), followed by the qualitative methods (16 articles) and lastly mixed methods ( 2 articles). 
Table 6: Research Approaches of Each Publication

\begin{tabular}{|l|l|l|l|}
\hline Year & \multicolumn{4}{l|}{ Research Approach } \\
\hline & Quantitative & Qualitative & Mixed mode \\
\hline 2018 & 1 & 1 & \\
\hline 2017 & 6 & 1 & 2 \\
\hline 2016 & 1 & 5 & \\
\hline 2015 & & 2 & \\
\hline 2014 & 3 & 4 & \\
\hline 2013 & 1 & & \\
\hline 2012 & & 1 & \\
\hline 2011 & 2 & & \\
\hline 2009 & 1 & 1 & \\
\hline 2007 & & 1 & \\
\hline 2004 & 1 & & \\
\hline 2000 & 1 & & \\
\hline Total & 17 & 16 & 2 \\
\hline
\end{tabular}

\section{List by Subject Area of Articles}

Table 7 shows the growth of each subject according to the year of publication and subject involved. In this analysis, author decided to divide the subject area according to research in Zakat for Islamic banking, research in Zakat for company, research in Zakat for agriculture and research in Zakat to the Zakat institution. Based on the result, the most subject area that has been conducted in Zakat Accounting research is Zakat for institution (18 article), secondly Zakat for company (14 article), Third Zakat for agriculture (2 article) and lastly Zakat for Islamic banking (1 article).

Table 7: List by Subject Area of Articles

\begin{tabular}{|c|l|l|l|l|}
\hline Year & $\begin{array}{l}\text { Zakat for } \\
\text { Islamic } \\
\text { Bank }\end{array}$ & $\begin{array}{l}\text { Zakat for } \\
\text { company }\end{array}$ & $\begin{array}{l}\text { Zakat for } \\
\text { agriculture }\end{array}$ & $\begin{array}{l}\text { Zakat } \\
\text { institution }\end{array}$ \\
\hline 2018 & & & & 2 \\
\hline 2017 & & 1 & 1 & 7 \\
\hline 2016 & & 3 & & 3 \\
\hline 2015 & & & & 2 \\
\hline 2014 & & 3 & 1 & 3 \\
\hline 2013 & 1 & & & \\
\hline 2012 & & 1 & & \\
\hline 2011 & & 1 & & 1 \\
\hline 2009 & & 2 & & \\
\hline 2007 & & 1 & & \\
\hline 2004 & & 1 & & \\
\hline 2000 & & 1 & & \\
\hline Total & 1 & 14 & 2 & 18 \\
\hline
\end{tabular}

Based on above overall analysis it has provided the following trend:

> Only 13 articles have been found in Scopus and 31 articles has been found in Goggle Scholar database. However, the actual amount of article related to Zakat Accounting is 35 articles.

$>$ The most article published are on 2017 (9 article, 27\%), and there is no article being published in the year 2001,2002,2003,2005,2006,2008, and 2010. However, the trend shows that they are increasing and constantly publish in the number of articles since 2011 onwards.

$>$ The most publishers publish article related to Zakat Accounting is Journal publisher 15 articles (46\%), International Journal publisher 8 articles (24\%), proceeding and conference publisher 6 articles (18\%) and others 4 articles (12\%).

$>$ The most document in Zakat Accounting publish in the Scopus and Goggle Scholar database is article (22 documents, 63\%), the second type of document is conference paper ( 6 documents, $15 \%$ ), the third type of document is review paper (5 documents, $14 \%$ ) and lastly thesis paper ( 2 document, $6 \%)$

$>$ The most articles (14 articles) are descriptive type in nature, followed by empirical (8 article), exploratory (8 articles) and lastly analytical (5 articles).

$>$ Most of the articles are quantitative methods (17 articles), followed by the qualitative methods (16 articles) and lastly mixed methods (2 articles).

$>$ The most subject area that has been conducted in Zakat Accounting research is Zakat for institution (18 article), secondly Zakat for company (14 article), Third Zakat for agriculture (2 article) and lastly Zakat for Islamic banking (1 article).

\section{CONCLUSIONS}

Zakat is the most powerful compulsory charity tools that establish by Islam to fight poverty and all unwanted consequences. The distribution of zakat fund must be distributed and handle carefully, since Islam has stated that only eight type of people are entitled to receive the zakat fund. Besides that, in context of Islam, The Muslim will also be considered sinful if they are not pay the zakat obligation if they are already meet the requirement stated in Islamic law. To compute and make an assessment, accounting will play a fundamental role to determine Zakat obligation. However, the principle business and accounting principle in Islamic perspective is different with conventional western type of business. Thus, the standard and the accounting treatment especially in Zakat perspective play an important role to make sure Muslim company comply with this Zakat obligation.

From above analysis it has been indicate that they are still lack of research been conducted in the area of Zakat Accounting. Only 35 articles has been found in Scopus and Goggle Scholar database related to Zakat Accounting from year 2000 until 2018. None of the article has been publish in the year 2001,2002,2003,2005,2006,2008, and 2010. 
However, the trend shows that they are increasing and constantly publish in the number of articles since 2011 onwards. It shows that the tendency of the researcher to do research in area of zakat accounting has been increasing from year to year. Since there are quite few articles published related to this field, it is important to researchers to continue their researches or studies in this Zakat Accounting field to contribute new knowledge and fil gaps in the area of Zakat Accounting. We hope by conducting this bibliometric analysis it will give some direction of the future research, gap identification and current trend regarding the Zakat Accounting area.

\section{REFERENCES}

[1] Haq, A., Ashraf, M., \& Omar, M. (2017). Zakat, Persistence of Poverty and StructuralIncidental Segmented Approach : A Survey of Literature. Ournal of Islamic Financial Studies, 3(1).

[2] Noor, A. M., \& Saad, R. A. J. (2016). The Mediating Effect of Trust on the Relationship between Attitude and Perceived Service Quality towards Compliance Behavior of Zakah. International Journal of Economics and Financial Issues, 6(7), 27-31.

[3] Akhyar Adnan, M., \& Barizah Abu Bakar, N. (2009). Accounting treatment for corporate zakat: a critical review. International Journal of Islamic and Middle Eastern Finance and Management, 2(1), 32-45.

[4] Ibrahim, S. M., \& Shaharuddin, A. (2015). In Search of an Effective Zakat Institution Management in Kano State Nigeria. Journal for Studies in Management and Planning, 01(07), 242-258.

[5] Mohd khairul Firdaus, W., \& Khairuldin, W. (2013). The Philosophy and Elasticity of Zakah Distribution in Islam. International Journal of Education and Research, 1(8), 1-12.

[6] Ahmed, E. R., Aiffin, K. H. Bin, \& Zuqebah3, T. T. Y. A. A. (2016). Zakat and Accounting Valuation Model. Journal of Reviews on Global Economics, 5, 16-24.

[7] Bar-Ilan, J. (2017). Bibliometrics and Research Evaluation: Uses and Abuses. YvesGingras. Cambridge, MA: MIT Press, 2016. 136 pp. \$26.00 (hardcover). (ISBN: 9780262035125). Journal of the Association for Information Science and Technology, 68(9), 2290-2292.

[8] Merigó, J. M., \& Yang, J. B. (2017). Accounting Research: A Bibliometric Analysis. Australian Accounting Review, 27(1), 71-100.

[9] Podsakoff, P. M., MacKenzie, S. B., Podsakoff, N. P., \& Bachrach, D. G. (2008). Scholarly influence in the field of management: A bibliometric analysis of the determinants of University and author impact in the management literature in the past quarter century. Journal of Management (Vol. 34).

[10] Lopez, J., Susarla, S. M., Swanson, E. W., Calotta, N., \& Lifchez, S. D. (2015). The association of the $\mathrm{H}$-index and academic rank among full-time academic hand surgeons affiliated with fellowship programs. Journal of Hand Surgery, 40(7), 1434-1441.

[11] De Sordi, J. O., Conejero, M. A., \& Meireles, M. (2016). Bibliometric indicators in the context of regional repositories: proposing the D-index. Scientometrics, 107(1), 235-258.

[12] Htay, S. N. N., \& Salman, S. A. (2014). Proposed Best Practices of Financial Information Disclosure for Zakat Institutions: A Case Study of Malaysia. World Applied Sciences Journal, 30(30 A), 288-294.

[13] Obaidullah, M. (2016). Revisiting estimation methods of business zakat and related tax incentives. Journal of Islamic Accounting and Business Research, 7(4), 349-364.

[14] Abdul Rahim, A. R. (2006). Pre-requisites for effective integration of zakah into mainstream Islamic financial system in Malaysia. Islamic Economic Studies, 14, 91-107.

[15] Abu Bakar, N. B., \& Abdul Rahman, A. R. (2007). A Comparative Study of Zakah and Modern Taxation. J. KAU: Islamic Economics, 20, 25-40.

[16] Zakari, A. (2000). A-Z Manual on Zakat (1st editio). Kano: Ahmed Zakari and Co. (Chartered Accountants).

[17] Hamat, Z. (2015). Harmonization of business zakat and taxation in Malaysia, 2, 183-189.

[18] Clarke, F., Craig, R., \& Hamid, S. (1996). Physical asset valuation and zakat: Insights and implications. Advances in International Accounting, 9, 195-208.

[19] Nor Aini, A. (2006). Analisis perakaunan zakat di Malaysia. Jurnal Syariah, 14, 35-47.

[20] Nur Barizah, A. B. (2007). A zakat accounting standard (ZAS) for Malaysian companies. The American Journal of Islamic Social Sciences, 24(August), 74-92.

[21] Hamat, Z. (2009a). Business Zakat Accounting and Taxation. In Conference on Islamic Perspectives on Management and Finance (pp. 13-18).

[22] Nugraha, S., Wardayati, S., \& Sayekti, Y. (2018). Implementation of Zakat Accounting In Amil Zakat Institute (LAZ) In Jember (Reviewed From Zakah Shariah: PSAK 101 And PSAK 109). International Journal of New Technology and Research (IJNTR), 4(1), 5257.

[23] Marhaini, M., \& Irwan, M. (2018). Implementation Psak 109 About Accounting Of Zakat At Baznas Of West Nusa Tenggara Province Indonesia. International Journal of 
Economics, Commerce and Management, $V 1(3)$.

[24] Sudjali, I. (2017). The accounting for zakat: The accountability of Indonesian zakat agencies.

[25] Tajuddin, T. S., Shamsudin, N., \& Mat Nor, F. (2017). Current Methods of Business Zakat Accounting in Malaysia. In Proceeding of the 4th International Conference on Management and Muamalah 2017 (ICoMM 2017) (pp. 584593).

[26] Nikmatuniyah, Marliyati, \& A, L. M. (2017). Effects of Accounting Information Quality, Accountability, and Transparency on Zakat Acceptance. MIMBAR, 33(1), 62-73.

[27] Restuningtyas, R. S., Marina, A., \& Nuraini, F. (2017). Accounting Of Zakat, Infak And Alms In Transparency And Accountability In Laz Dompet Amanah Umat Sidoarjo. Journal.umSurabaya.ac.id, XIV(1).

[28] Hanapi, M. S., \& Wan Khairuldin, W. M. K. F. (2017). The Relationship between Paddy Zakat Accounting and the Social Wellbeing Aspect of Farmers in Perlis, Malaysia. International Journal of Academic Research in Business and Social Sciences, 7(6).

[29] Komala, A. R. (2017). Cause and effect of accounting information system: A study in national Zakat management organization. Journal of Administrative and Business Studies, 3(2).

[30] Nurhayati, N., \& Susanto, A. (2017). The influence of Transformational Leadership on the Success of Accounting Information Systems Implementation (Survey on National Zakat Management Institution of West Java). Journal Of Engineering and Applied Sciences, 12(17), 4534-4539.

[31] Nurunnabi, M. (2017). IFRS and Saudi accounting standards: a critical investigation. International Journal of Disclosure and Governance, 14(3), 191-206.

[32] Nurhayati, N., Susanto, A. (2017). The influence of transformational leadership on the success of accounting information systems implementation (Survey on national Zakat management institution of West Java). Journal of Engineering and Applied Sciences, 12(17), 4534-4539.

[33] Hasibuan, H. T. (2016). Statement of Financial Accounting Standard (PSAK) No. 109 and Its Implementation in Several Zakat Management Organizations in Malang, East Java. Shirkah: Journal of Economics and Business, 1(3), 339.

[34] Harianto, S. (2016). Accounting For Zakat on Income Critical Study Based on Government Regulation (Case Study in Aceh Province of Indonesia). International Journal ofBusiness, Accounting and Management, 1(3), 47-52.
[35] Jaelani, A. (2016). Zakat Accounting: Metaphor and accounting treatment for business organization. Munich Personal RePEc Archive.

[36] Habib, A. A. (2016). The Principle of Zakat, Infaq, and Shadaqah Accounting Based Sfas 109. Journal of Accounting and Business Education, 1(1).

[37] Alim, M. N. (2015). Utilization and Accounting of Zakat for Productive Purposes in Indonesia: A Review. Procedia - Social and Behavioral Sciences, 211, 232-236.

[38] Suffitra, R. (2015). Badan Amil Zakat Daerah Kabupaten Banyuwangi) Implementation Of Accounting Zakat at The Organization Of Zakat Based On SFAS 109 About Accounting Zakat .... Artikel Ilmiah Mahasiswa.

[39] Tajuddin, T., Aman, Z., \& Ismail, S. (2014). Management Accounting Practices In NonProfit Religious Organization: A Case Study In Lembaga Zakat Selangor (Lzs). Synergizing Knowledge on Management and Muamalah.

[40] Hanapi, M. S. (2014). Agricultural Zakat Accounting in Malaysia. International Journal of Business and Social Science, 5(5), 178-185.

[41] Wasila, S., \& Shonhadji, N. (2014). A study on the zakat and infaq or sodaqoh accounting application under SFAS 109 in Al-Falah Social Fund Foundation (YDSF) Surabaya. The Indonesian Accounting Review, 4(2), 169-174.

[42] Sanusi, N. A. B. T. (2014). The dynamics of capital structure in the presence of zakat and corporate tax. International Journal of Islamic and Middle Eastern Finance and Management, 7(1), 89-111.

[43] Hamat, Z. (2014). Sustainable Zakat Accounting in Malaysia: An Analysis. Mediterranean Journal of Social Sciences, 5, 139-146.

[44] Al-Riyami, A., Al-Amri, A., One, K. A.-B.-V., \& 2014, undefined. (n.d.). Zakat expert system. Books.google.com.

[45] Amalina Wan Abdullah, W., Percy, M., \& Stewart, J. (2013). Shari'ah disclosures in Malaysian and Indonesian Islamic banks:The Shari'ah governance system. Journal of Islamic Accounting and Business Research, 4(2), 100131.

[46] Komala, A. R. (2012). The influence of the accounting managers' knowledge and the top managements' support on the accounting information system and its impact on the quality of accounting information: a case of zakat institutions in bandung. Journal of Global Management, 4(1), 053-073.

[47] Yusuf, S. N. B. S. (2011). Changes in management accounting, innovation and person job fit practices in Lembaga Zakat Selangor. 
[48] Noor, R. M., Rashid, \& Mastuki, N. (2011). Zakat and tax reporting: Disclosures practices of Shariah compliance companies. In 2011 IEEE Colloquium on Humanities, Science and Engineering (pp. 877-882). IEEE.

[49] Hamat, Z. (2009b). Business Zakat Accounting and Taxation in Malaysia. In Conference on Islamic Perspectives on Management and Finance.

[50] Bakar, N. B. A. (2007). A Zakat Accounting Standard (ZAS) For Malaysian Companies. The American Journal of Islamic Social Sciences, 24, 19.
[51] Zaid, O. A. (2004). Accounting System And Recording Procedures In The Early Islamic State. Accounting Historians Journal, 31(2), 149-170.

[52] Zaid, O. A. (2000). Were Islamic Records Procursors To Accounting Books Based On The Italian Methods? Accounting Historians Journal, 27(1), 73-90.

[53] Sekaran, U., \& Bougie, R. (2016). Research methods for business: A skill building approach. John Wiley \& Sons.

[54] Punch, K. F., \& Oancea, A. (2014). Introduction to Research Methods in Education. SAGE. 